10 Simes JR, Weaver DW, Ellis SG, Grines CL. Overview of the randomised trials of primary PTCA and thrombolysis in acute myocardial infarction [abstract]. Circulation 1997;94(suppl):I331.

11 ISIS-3 collaboration group. A randomised comparison of streptokinase vs tissue plasminogen activator vs anistrestreptokinase vs tissue plasminogen activator vs anistre-
plase and of aspirin plus heparin vs aspirin alone among plase and of aspirin plus heparin vs aspirin alone among
41,299 cases of suspected acute myocardial infarction. 41,299 cases of suspect
Lancet $1992 ; 339: 753-70$.

12 The GUSTO IIb Investigators. A comparison of recombinant hirudin with heparin for the treatment of acute coronary syndromes. $N$ Engl $f$ Med 1966;335:775-82.

13 RITA trial participants. Coronary angioplasty versus coronary artery bypass surgery: the randomised intervention treatment of angina (RITA) trial. Lancet 1993;341: 573-80.

14 TIMI IIIB investigators. Effects of tissue plasminogen activator and a comparison of early invasive and conservative strategies in unstable angina and non-Q-wave myocardial infarction. Results of the TIMI IIIB trial. Thrombolysis in myocardial ischemia. Circulation 1994;89:1545-56.

in myocardial ischemia. Circulation 1994;89:1545-56.
15 Every NR, Parsons LS, Haltky M, et al. For the MITI Every NR, Parsons LS, Haltky M, et al. For the MITI
investigators. A comparison of thrombolytic therapy with investigators. A comparison of thrombolytic therapy with primary coronary angioplasty for acute
tion. $N$ Engl $₹$ Med 1996;335:1253-60.

16 de Boer MJ, van Hout BA, Liem AL, Suryapranata $H$, Hoorntje JCA, Zijlstra F. A cost-effective analysis of primary coronary angioplasty versus thrombolysis for acute myocardial infarction. Am $\mathcal{F}$ Cardiol 1995;76:830-3.
17 Stone GW, Grines CL, Rothbaum D, et al. Analysis of the relative costs and effectiveness of pimary angioplasty versus tissue-type plasminogen activator: the primary angioplasty in myocardial infarction (PAMI) trial. $7 \mathrm{Am}$ Coll Cardiol 1997;29:901-7.

18 Zahn R, Vogt A, Neuhaus K-L, Schuster S, Senges J for the ALKK study group. Angioplasty in acute myocardial infarction in clinical practise: results in 4625 patients infarction in clinical practise: results in 4625 patients from the ALKK angioplasty reg
Cardiol 1997;29(suppl A):15A.

19 European Working Party. Streptokinase in recent myocardial infarction: a controlled multicentre trial. $B M \mathcal{F}$ 1971;3:325-31.

20 Yusuf S, Collins R, Peto R, et al. Intravenous and intracoronary fibrinolytic therapy in acute myocardial infarction: overview of results on mortality, reinfarction and side effects from 33 randomised controlled trials. Eur Heart $\mathcal{f} 1985 ; 6: 556-85$

21 Fibrinolytic Therapy Trialists' (FTT) Collaborative Group. Indication for fibrinolytic therapy in suspected acute myocardial infarction: collaborative overview of acute myor patis from all randomised trials of more than 1000 patients. Lancet

22 ISIS-2 (Second International Study of Infarct Survival) collaboration group. Randomised trial of intravenous streptokinase, oral aspirin, both, or neither among 17187 cases of acute myocardial infarction. Lancet 1988,ii: 349-60.

\title{
Is primary angioplasty feasible or will we provide a two-tier service?
}

\section{Pascal Chatelain, Philip Urban}

Primary angioplasty for acute myocardial infarction has its fans, its doubters, and those (the majority) who belong to neither camp because they have no choice other than thrombolysis to achieve myocardial reperfusion in their institution. Should they feel inadequate and guilty not to be in a position to offer the "best" treatment? Should they all start a hard and long fight with their administration for an increased share of scarce resources? In other words, should the clinical superiority of primary angioplasty, be used as an argument for the availability of catheterisation laboratories and interventionists in every hospital? A responsible answer to these questions should probably be negative.

To abandon thrombolysis as the treatment of choice for acute myocardial infarction would certainly be a mistake as it has several advantages over primary angioplasty. First, if appropriately prescribed, its administration by a general practitioner or a junior casualty doctor will be as effective as when given by the most experienced cardiologist. Second, thrombolysis can be administered out of hospital when geographical constraints make this necessary. ${ }^{1}$ Third, new thrombolytic agents are under investigation with the common aim to achieve TIMI-3 flow more rapidly in a larger number of patients. ${ }^{2}$

On the other hand, several advantages of primary angioplasty remain. Overall analysis of more than 2000 patients randomised in eight studies so far demonstrates a significant mortality reduction of angioplasty compared with thrombolysis, and the rare but devastating occurrence of intracerebral bleeding is also avoided. ${ }^{3}$ Coronary anatomy and left ventricular function are assessed immediately, allowing better therapeutic decisions including early discharge. ${ }^{4}$ The efficacy of reperfusion can be monitored directly and eventually modified by further mechanical and pharmaceutical interventions. Finally, this treatment allows the patient to be in expert hands during the acute phase of the disease.

However, recent multicentre data from the GUSTO IIb trial ${ }^{5}$ suggest that the overall differences between primary angioplasty and accelerated tissue plasminogen activator ( $t-$ PA) are rather small, and point to the need for subgroup analysis. High risk patients, and probably patients with a contraindication to thrombolysis, are emerging as those with the best indications for primary angioplasty.

After a rather unequal competition between both strategies during the first 10 years of the reperfusion era, an unpleasant and unjustified feeling of revenge has been perceptible behind several affirmations favouring primary angioplasty. We should stop competing and concentrate on the real issues. These include making primary angioplasty available for the subset of patients most likely to benefit from the procedure, and organising adequate referral networks. It must then be the responsibility of every physician to make the best decision after a thorough (but swift) evaluation of the individual patient's situation.

1 GREAT Group. Feasibility, safety, and efficacy of domiciliary thrombolysis by general practitioners: Grampian region early anistreplase trial. $B M \mathcal{F}$ 1992;305:548-3.

2 Fuster V. Coronary thrombolysis - a perspective for the practicing physician. $N$ Engl f Med 1993;329:723-5.

3 Michels KB, Yusuf S. Does PTCA in acute myocardial infarction affect mortality and reinfarction rates? A infarction affect mortality and reinfarction rates? A quantitative overview (meta-analysis) of
clinical trials. Circulation 1995;91:476-85.

4 Brodie B, Grines CL, Spain M, Griffin J, Balestrini C, Stone GW, et al. A prospective, randomized trial evaluating early discharge (day 3) without non-invasive risk stratification in low risk patients with acute myocardial infarction: PAMI-2 [abstract]. $f \mathrm{Am}$ Coll Cardiol 1995; infarction: $\mathrm{PAN}$

5 The GUSTO-IIb Angioplasty Subgroup Investigators. An international randomized trial of 1138 patients comparing primary coronary angioplasty versus tissue plasminogen activator for acute myocardial infarction. $N \mathrm{Engl} \mathcal{F} \mathrm{Med}$ 1997;336:1621-8. 